Rev.MVZ Córdoba 20(2):4629-4635, 2015. ISSN: 0122-0268

SHORT COMMUNICATION

\title{
Estimation of milk production in hair ewes by two methods of measurement
}

\section{Estimación de la producción de leche en ovejas de pelo mediante dos métodos de medición}

\author{
Irina Peniche G, ${ }^{1 *}$ M.Sc, Luis Sarmiento $F^{1}$ Ph.D, Ronald Santos R, ${ }^{1}$ Ph.D.
}

\begin{abstract}
${ }^{1}$ Autonomous University of Yucatan, Faculty of Veterinary Medicine and Animal Science, Department of Animal Nutrition, Carr. Mérida-X'matkuil km 15.5, Apdo. 4-116 Itzimná, CP 97100, Mérida, Yucatán, México. *Corresponding: ironadieska@gmail.com
\end{abstract}

Received: June 2014; Accepted: December 2014.

\begin{abstract}
Objective. The objective of the current study was to compare two methods to estimate daily milk production in crossbred hair ewes. Materials and methods. Eight multiparous, crossbred (Pelibuey $\mathrm{x}$ Katahdin) lactating hair ewes were used in a completely randomized design with repeated measurements, for 56 days. Ewes were fed ad libitum with a diet based on concentrate. Milk production was estimated twice a week for each ewe by both methods, suckled-hand (SH) and weigh-suckle-weigh (WSW) method. Results. Milk production ( $p>0.05$ ) means were 1031.9 \pm 95.6 and $1119.0 \pm 95.6 \mathrm{~g} /$ day/ewe for $\mathrm{SH}$ and WSW method, respectively. Conclusions. No significant differences $(p>0.05)$ were found between methods for milk yield.
\end{abstract}

Key words: Hand milking, lambs, weighing (Source: AGROVOC).

\section{RESUMEN}

Objetivo. El objetivo del presente trabajo fue comparar dos métodos para estimar la producción diaria de leche en ovejas de pelo cruzadas. Materiales y métodos. Se utilizaron ocho ovejas multíparas, cruzadas (Pelibuey x Katahdin) y lactantes, en un diseño completamente al azar, con medidas repetidas, durante 56 días. Las ovejas fueron alimentadas ad libitum con una dieta basada en concentrado. La producción de leche se estimó dos veces a la semana a cada oveja, mediante ambos métodos, el doble pesaje del cordero-ordeño manual de la ovejas (DPC-OMO) y el doble pesaje

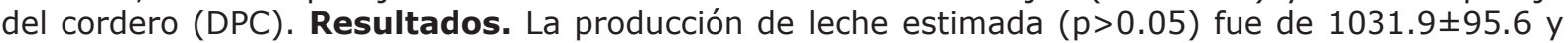
$1119.0 \pm 95.6 \mathrm{~g} /$ día/ovejas para el DPC-OMO y DPC, respectivamente. Conclusión. No se encontraron diferencias significativas ( $p>0.05$ ) entre métodos de estimación de la producción de leche.

Palabras clave: Corderos, ordeño manual, pesaje (Fuente: AGROVOC). 


\section{INTRODUCTION}

Daily milk intake is the most important factor in determining lamb growth rate; therefore survival and potential growth of lambs depend on lactation of the dam. Due to the influence of milk yield on weaning weight and to the large variation in milking ability among the genotypes available in tropical areas, the estimation of milk production by lactating ewes contributes with useful information for the implementation of management strategies for ewes and their lambs. Direct measurement of milk production in non-dairy tropical sheep is difficult. For these reasons direct (e.g. hand or mechanic milking) and indirect (e.g. weigh-suckle-weigh method, udder dimensions) methods are commonly used to estimate milk production, however, these methods have demonstrated inaccurate results $(1,2)$.

One of the most cited methods for measuring milk production is the weigh-suckle-weigh (WSW) method $(3,4)$. Some authors describe that use of the WSW method can generate underestimation of milk production at the beginning of lactation $(1,5)$, mainly in ewes with single lambing. For this reason, other authors modified the WSW method (6), by adding a hand milking after second weighing of the lamb, in an attempt to obtain a valid estimation of milk production. The evaluation or comparison of methods to estimate milk yield in non-dairy tropical sheep has been little documented; however some authors reported milk production of $1029 \mathrm{~g} /$ day in Pelibuey ewes at the first 20 days post-lambing by WSW method (7). The objective of the current study was to compare two methods to estimate daily milk production in crossbred hair ewes.

\section{MATERIALS AND METHODS}

Study site. The study was conducted at the Faculty of Veterinary Medicine and Animal Science, Autonomous University of Yucatan $\left(20^{\circ} 58^{\prime} \mathrm{N}\right.$ and $\left.89^{\circ} 37^{\prime} \mathrm{O}\right)$ Yucatan, Mexico. The climatic conditions in the study area correspond to the AWO classification, characterized as warm and subhumid with a single rainy season between May and October, annual rainfall from 800 to $1000 \mathrm{~mm}$, annual temperature from 26 to $28^{\circ} \mathrm{C}$ and relative humidity between $65-85 \%$ (8).

Animals and experimental design. In this trial eight multiparous hair ewes (Pelibuey $x$ Katahdin) with single lamb (five females and three males) and average body weight (BW) of $42.93 \pm 9.93$ $\mathrm{kg}$ were used in a completely randomized design with repeated measurements. Animals were

\section{INTRODUCCIÓN}

El consumo diario de leche es el factor más importante en la determinación de la tasa de crecimiento del cordero; por consiguiente la supervivencia y el crecimiento potencial de los corderos depende de la lactancia de la madre. Debido a la influencia de la producción de leche sobre el peso al destete y a la gran variación en la habilidad lechera entre los fenótipos disponibles en las áreas tropicales, la estimación de la producción de leche en ovejas en lactación contribuye con información útil para la implementación de estrategias de manejo para las ovejas y sus corderos. La medición directa de la producción de leche en ovejas tropicales no lecheras es difícil. Por estas razones, los métodos directos (ej. Ordeño mecánico o manual) e indirectos (ej. Doble pesaje del cordero, dimensiones de la ubre) son los más comúnmente usados para estimar la producción de leche, sin embargo, estos métodos han demostrado resultados imprecisos. $(1,2)$.

Uno de los métodos más citados para la medición de la producción de leche es el método del doble pesaje del cordero (DPC) $(3,4)$. Algunos autores describen que el uso del método DPC puede generar una subestimación de la producción de leche al principio de la lactancia $(1,5)$ principalmente en ovejas con una sola cría. Por este motivo, otros autores modificaron el método DPC (6) adicionando un ordeño manual luego del segundo pesaje del cordero, tratando de obtener una estimación de producción de leche válida. La evaluación o comparación de los métodos para estimar la producción de leche en ovejas tropicales no lecheras ha sido poco documentada; sin embargo algunos autores reportaron producción diaria de leche de 1029 g/día en ovejas Pelibuey durante los primeros 20 días post-parto con el método DPC (7). El objetivo del presente estudio fue comparar dos métodos para estimar la producción diaria de leche en ovejas de pelo cruzadas.

\section{MATERIALES Y MÉTODOS}

Sitio de estudio. El estudio fue llevado a cabo en la Facultad de Medicina Veterinaria y Zootecnia, Universidad Autónoma de Yucatán $\left(20^{\circ} 58^{\prime} \mathrm{N}\right.$ and $89^{\circ} 37^{\prime}$ O) Yucatán, México. Las condiciones climáticas del área de estudio corresponden a la clasificación AWO, caracterizada como cálida y subhúmeda con una sola temporada de lluvias entre mayo y octubre, con precipitación anual de 800 a $1000 \mathrm{~mm}$, temperatura anual de 26 a $28^{\circ} \mathrm{C}$ y humedad relativa entre el 65 $y$ el $85 \%(8)$.

Animales y diseño experimental. Durante esta prueba, ocho ovejas de pelo multíparas (Pelibuey $x$ Katahdin) con una sola cría (cinco hembras 
individually housed $(2.5 \times 2.0 \mathrm{~m})$ with their lambs in pens equipped with feed and water containers. The experimental period was the first 56 days of lactation, considering the first seven days as an adaptation period. Ewes were fed ad libitum with a diet based on concentrate, $10.25 \%$ crude protein (CP) and $12.32 \mathrm{MJ} / \mathrm{kg}$ dry matter (DM) of metabolizable energy (ME), balanced according to NRC (9) requirements. Pens and feed containers were arranged so that the lambs have no access to the dam's feed. Ewes were dewormed after lambing by an intramuscularly application of Levamisole (Aranda Laboratories, Queretaro, Qro., Mexico).

Milk production was estimated twice a week for each ewe by both methods, suckled-hand (SH) method (6) and weigh-suckle-weigh (WSW) method (10), from the second to the eighth week of lactation.

Milk estimation through SH method. Once a week, lambs were separated from their dams for $12 \mathrm{~h}$ beginning at 20:00 h. The day after lambs were weighed with a digital weighing scale $(5 \mathrm{~g} / \mathrm{kg}$ of precision) at $8: 00 \mathrm{~h}$ and at that moment they were allowed to suckle the ewe for 10 minutes, then lambs were weighed again immediately to estimate the amount of milk suckled. Additionally, after suckling, the ewes were hand milked soon after to get the milk left in their udders and this quantity of milk was recorded. In order to obtain the residual milk in dams an intramuscular injection of three IU of synthetic oxytocin (Aranda Laboratories, Queretaro, Qro., Mexico) was used. During the separation period lambs were located in pens allowing sight and smell contact with their dams and avoiding suckling. After milk measurement lambs were kept with their dams the rest of the day. Daily milk production was calculated by summing up the milk suckled by lambs (difference between lamb's weights) and milk obtained by hand milking. Then, the result of this calculation was multiplying by two, with the aim to extrapolate the estimation of the milk production in $24 \mathrm{~h}$ period.

Milk estimation through WSW method. Once a week, lambs were separated at 3:00 a.m. from their dams for three hours and after that, they were allowed to suckle for 10 minutes. Then, lambs were separated again from the ewes for three hours. During the separation time lambs were located in pens allowing sight and smell contact with their dams and avoiding suckling. After this second separation period $(9: 00 \mathrm{~h})$, lambs were weighed and then they were allowed to suckle the ewe for 10 minutes, after that they immediately were weighed again. The difference y tres machos) y peso vivo (PV) promedio de $42.93 \pm 9.93 \mathrm{~kg}$ fueron utilizados en un diseño completamente al azar con medidas repetidas. El periodo experimental fueron los primeros 56 días de lactancia, considerando los primeros siete días como un periodo de adaptación. Las ovejas fueron alimentadas ad libitum con una dieta basada en concentrado, $10.25 \%$ proteína cruda (PC) y $12.32 \mathrm{MJ} / \mathrm{kg}$ de materia seca (MS) de energía metabolizable (EM), balanceada de acuerdo a los requerimientos del NRC (9). Los corrales y contenedores de alimentos fueron organizados para que los corderos no tuvieran acceso al alimento de las madres. Las ovejas fueron desparasitadas luego del parto mediante la aplicación intramuscular de Levamisol (Laboratorios Aranda, Querétaro, Qro., México).

La producción de leche fue estimada dos veces por semana para cada oveja mediante ambos métodos, doble pesaje del cordero-ordeño manual de la oveja (DPC-OMO) (6) y doble pesaje del cordero (DPC) (10) desde la segunda hasta la octava semana de lactancia.

Estimación de leche con el método DPCOMO. Una vez por semana, los corderos fueron separados de sus madres por $12 \mathrm{~h}$ desde las 20:00 h. Al día siguiente los corderos fueron pesados a las $8: 00 \mathrm{~h}$ con una balanza digital ( $5 \mathrm{~g} / \mathrm{kg}$ de precisión) y en ese momento se les permitió amamantar a la oveja por 10 minutos. Inmediatamente después, los corderos fueron pesados nuevamente para estimar la cantidad de leche consumida. Adicionalmente, después del amamantamiento, las ovejas fueron ordeñadas manualmente poco después para recolectar la leche restante en las ubres y esta cantidad de leche fue medida. Con el fin de obtener la leche residual en las madres se usó una inyección intramuscular de tres UI de oxitocina sintética (Laboratorios Aranda, Querétaro, Qro., México). Durante el periodo de separación los corderos fueron ubicados en corrales permitiendo contacto de vista y olfato con sus madres y evitando el amamantamiento. Luego de la medición de leche los corderos se mantuvieron con sus madres durante el resto del día. La producción diaria de leche se calculó sumando la leche amamantada por los corderos (diferencia entre los pesajes del cordero) y la leche obtenida por ordeño manual. Luego, el resultado de este cálculo fue multiplicado por dos, para extrapolar la estimación de la producción de leche en un periodo de $24 \mathrm{~h}$.

Estimación de leche con el método DPC. Una vez por semana, los corderos fueron separados a las 3:00 a.m. de sus madres por tres horas y después de esto se les permitió amamantar por 10 
between pre and post-suckling weights was defined as milk consumption and consequently milk production. This recording was made over the $12 \mathrm{~h}$ period $(6: 00,9: 00,12: 00,15: 00$ and $18: 00 \mathrm{~h}$ ). Then, the daily milk production was calculated by summing up the estimations recorded and multiplying the result by two.

Ethics aspects. The present trial was approved by the Bioethic Committee at the Faculty of Veterinary Medicine and Animal Science of the Autonomous University of Yucatan.

Statistical analysis. Repeated measurements for estimations of weekly milk production was conducted using MIXED procedure of SAS (11). The fixed effects were the methods of estimation of milk production and the random effects were the animals. Additionally, orthogonal regression analysis was used to verify if both methods provide comparable milk production measurements. Orthogonal regression is useful when both axis, the predictor $(x)$ and answer $(y)$, have estimation error. Accordingly, the WSW method was considered the predictor for the $\mathrm{SH}$ method in the milk production estimation. The error variance ratio ( $\sigma \mathrm{SH} / \sigma$ WSW) was estimated and included in the orthogonal regression analysis using Minitab (12).

\section{RESULTS}

Mean milk production of hair ewes measured using two different methods are presented in table 1 . No significant differences ( $p>0.05$ ) were found between methods for estimate the milk production. Daily estimation of milk production showed similar coefficient of variation ( 0.35 for $\mathrm{SH}$ and 0.34 for WSW method).

Milk production between weeks (Figure 1) was different $(p \leq 0.05)$. At the seventh post-lambing week there was significant difference $(p \leq 0.05)$ in the estimation of milk production (1043 and 1497 $\mathrm{g} /$ day for $\mathrm{SH}$ and WSW, respectively) according to the method used.

Table 1. Weekly estimation of milk production by two methods of measurements.

\begin{tabular}{cc} 
Method & Milk production, g/day \\
\hline Suckled-hand & 1031.9 \\
Weigh-suckle-weigh & 1119.0 \\
Standard error & 95.6 \\
p-value & 0.55 \\
\hline
\end{tabular}

minutos. Luego, los corderos fueron nuevamente separados de sus madres por tres horas. Durante el periodo de separación los corderos fueron ubicados en corrales permitiendo contacto de vista y olfato con sus madres y evitando el amamantamiento. Luego de este segundo periodo de separación (09:00h), los corderos fueron pesados y se les permitió amamantar por 10 minutos y luego fueron nuevamente pesados. La diferencia entre los pesos del pre y post amamantamiento fue definida como el consumo de leche y por consiguiente producción de leche. Este registro fue hecho durante un periodo de 12h (6:00, 9:00, 12:00, 15:00 y 18:00 h). Posteriormente, la producción diaria de leche fue calculada sumando las estimaciones registradas y multiplicando el resultado por dos.

Aspectos éticos. Esta prueba fue aprobada por el Comité de Bioética de la Facultad de Medicina Veterinaria y Zootecnia de la Universidad Autónoma de Yucatán.

Análisis estadístico. Se llevaron a cabo medidas repetidas para las estimaciones semanales de la producción de leche usando el procedimiento MIXED de SAS (11). Los efectos fijos fueron los métodos de estimación de la producción de leche y los efectos aleatorios fueron los animales. Adicionalmente, un análisis de regresión ortogonal fue utilizado para verificar si los dos métodos proporcionaban mediciones comparables de la producción de leche. La regresión ortogonal es útil cuando ambos ejes, el predictor $(x)$ y la respuesta $(y)$, tienen error de estimación. Por consiguiente, el método DPC fue considerado como predictor para el método DPC-OMO en la estimación de la producción de leche. La relación de la varianza del error ( $\sigma D P C-$ $\mathrm{OMO} / \sigma \mathrm{DPC}$ ) fue estimada e incluida en el análisis de regresión ortogonal usando Minitab (12).

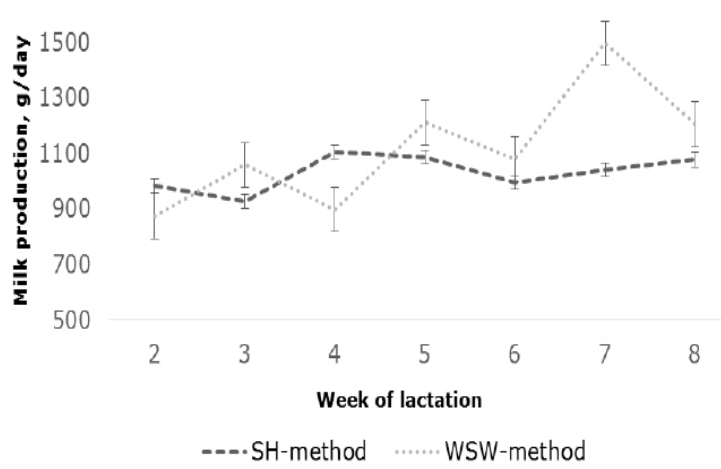

Figure 1. Weekly milk production ( $\mathrm{g} / \mathrm{day}$ ) of hair ewes estimated by two methods, suckled-hand (SH) and weigh-suckle-weigh (WSW), of measurements. 
The orthogonal regression (Table 2), shows no significant difference $(p>0.05)$ between methods in the estimation of milk production coefficient. The confidence intervals (95\%) for the intercept (a) and the slope (b), included $0(p>0.05)$ and $1(p \leq 0.001)$, respectively. Moreover, the errorvariance ratio (SH/WSW) between methods around 1 suggests equality in the estimation by both methods.

Table 2. Orthogonal regression coefficient to compare the estimation of milk production by two methods (SH and WSW) of measurements.

\begin{tabular}{|c|c|c|c|c|c|}
\hline Item & $\mathbf{a}$ & $\begin{array}{c}\text { P-value } \\
\text { (Intercept) }\end{array}$ & B & $\begin{array}{l}\text { P-value } \\
\text { (slope) }\end{array}$ & $\begin{array}{l}\text { Variance of } \\
\text { error ratio } \\
\text { (SH/WSW) }\end{array}$ \\
\hline MP & $\begin{array}{c}-9.87 \\
(\mathrm{SE} 297.21)\end{array}$ & 0.97 & $\begin{array}{c}0.93 \\
(\mathrm{SE} 0.26)\end{array}$ & 0.00 & 0.87 \\
\hline
\end{tabular}

MP: milk production, SH: suckled-hand, WSW: weigh-suckle-weigh, SE: standard error.

\section{DISCUSSION}

The estimation of milk production by the methods used in this study was similar to the results reported in Pelibuey ( $1029 \mathrm{~g} /$ day) and Karadi ewes (1223 g/day) by different authors $(6,7)$ and higher than the results described $(603-750 \mathrm{~g} /$ day $)$ in West African ewes $(4,13)$.

The maximum milk production for the $\mathrm{SH}$ method in the fourth post-lambing week is in agreement with other studies $(6,14)$ where the production peak were reached between the third and fifth week of lactation. In the normal curve of lactation, close to the third week, a peak of lactation is expected (6). Furthermore, some authors have reported that milk production on non-dairy sheep maintains a maximum level during the first four or five weeks of lactation (2).

On the contrary, the peak of milk production with the WSW method disagrees with the literature as it reaches the maximum level lately; at seventh week normally milk production decreases (15). It could be partially related to the fact that methods used to measure milk production have the potential to interfere with the natural behaviour of the dam and her young. Besides, it is considered that in early lactation the WSW method can generate underestimation of milk production when a single lamb is used, as in this study, considering that in non-dairy ewes there is surplus milk in the udder at the beginning of

\section{RESULTADOS}

Los promedios de la producción de leche en ovejas de pelo medida utilizando dos métodos diferentes se presenta en la tabla 1 . No se encontraron diferencias significativas $(p>0.05)$ entre ambos métodos para estimar la producción de leche. La estimación diaria de la producción de leche mostró un coeficiente de variación similar (0.35 para DPC-OMO y 0.34 para DPC).

La producción entre semanas (Figura 1) fue diferente $(p \leq 0.05)$. En la séptima semana postparto hubo diferencia significativa $(p \leq 0.05)$ en la estimación de la producción de leche (1041 y 1497 g/día para DPC-OMO y DPC, respectivamente) de acuerdo con el método utilizado.

La regresión ortogonal (Tabla 2 ) no muestra diferencia significativa $(p>0.05)$ entre métodos en el coeficiente de estimación de la producción de leche. Los intervalos de confianza (95\%) para el intercepto (a) y la pendiente (b), incluyeron al $0(p>0.05)$ y al $1(p \leq 0.01)$, respectivamente. Además, la relación de la varianza del error ( $\sigma D P C-O M O / \sigma$ DPC) entre métodos cercana a 1 sugiere igualdad en la estimación hecha por ambos métodos.

\section{DISCUSIÓN}

La estimación de la producción de leche con los métodos utilizados en este estudio fue similar a los resultados reportados en ovejas Pelibuey $(1029 \mathrm{~g} /$ día) y Karadi (1223 g/día) por diferentes autores $(6,7)$ y mayor que los resultados $(603-750 \mathrm{~g} / \mathrm{día})$ descritos para ovejas West African $(4,13)$.

La producción máxima de leche para el método DPC-OMO ocurrió en la cuarta semana post-parto y está de acuerdo con otros estudios $(6,14)$ donde el pico de producción se alcanzó entre la tercera y quinta semana de lactancia. En la curva normal de la lactancia, el pico de la lactancia es esperado cerca de la tercera semana (6). Adicionalmente, algunos autores han reportado que la producción de leche en ovejas no lecheras mantiene un nivel máximo durante las primeras cuatro o cinco semanas de lactación (2).

Por el contrario, el pico de la producción de leche con el método DPC no concuerda con la literatura ya que alcanza el máximo nivel tardíamente; en la séptima semana la producción de leche normalmente decrece (15). Esto podría estar parcialmente relacionado con el hecho de que los métodos utilizados para medir producción de leche tienen el potencial para interferir con el comportamiento natural de la madre y sus crías. Además, se considera que en la lactancia temprana 
lactation which small lambs are not able to ingest (1).

The results of the orthogonal regression for both methods showed that the estimation of milk production with $\mathrm{SH}$ method is comparable with the measurement by WSW method.

Since estimation of the weekly milk production did not show significant difference between methods and both methods showed a similar coefficient of variation, it is concluded that both methods can be used in hair ewes; however, the authors of the present study consider that the $\mathrm{SH}$ method requires less animal management, which support the use of that under experimental conditions.

\section{Acknowledgements}

The first author would like to express her gratitude to the International Center for Development and Decent Work (ICDDGermany) and to the Consejo Nacional de Ciencia y Tecnologia (CONACYT-México) for the PhD scholarships awarded. el método DPC puede generar una subestimación de la producción de leche cuando se utiliza una sola cría, como en este estudio, considerando que en las ovejas no lecheras hay un excedente de leche en la ubre al principio de la lactancia, el cual los pequeños corderos no alcanzan a ingerir (1).

Los resultados de la regresión ortogonal para ambos métodos mostraron que la estimación de la producción de leche con el método DPC-OMO es comparable con la medición con el método DPC.

Debido a que la estimación de la producción semanal de leche no mostró diferencias significativas entre métodos y ambos métodos mostraron un coeficiente de variación similar, se concluye que ambos métodos pueden ser utilizados en ovejas de pelo; sin embargo, los autores de este estudio consideran que el método DPC-OMO requiere un manejo menor del animal, lo cual soporta el uso de este bajo condiciones experimentales.

\section{Agradecimientos}

El primer autor quisiera expresar su gratitud al Centro International para el Desarrollo y Trabajo Decente (ICDD - Alemania) y al Consejo Nacional de Ciencia y Tecnología (CONACyT - México) por las becas de doctorado otorgadas.

\section{REFERENCES}

1. Van der Linden DS, Lopez-Villalobos N, Kenyon PR, Thorstensen E, Jenkinson CMC, Peterson SW, Blair HT. Comparison of four techniques to estimate milk production in singleton-rearing non-dairy ewes. Small Rum Res 2010; 90(1-3): 18-26.

2. Ünal N, Atasoy $F$, Akçapinar $\mathrm{H}$, Koçak S, Yakan A, Erol H, Uğurlu, M. Milk yield measured by oxytocin plus hand milking and weigh-suckleweigh methods in ewes originating from local crossbred in Turkey. Rev Méd Vét 2007; 158(6): 320-325.

3. Nezamidousta N, Kominakisb A, Safari A. Use of Wood's model to analyze the effects of milking methods on lactation curve in sheep. Small Rum Res 2013; 113(1): 195-204.

4 Espinoza JC. Producción y composición de la leche y composición corporal de la borrega Pelibuey lactante, alimentada con tres niveles de energía metabolizable. [Ph.D Thesis]. Merida: University of Yucatan; 2014.
5. Aboul-Naga AM, El-Shobokshy AS, Moustafa MA. Milk production from subtropical non-dairy sheep 2. Method of measuring. J Agric Sci 1981; 97(02): 303-308.

6. Baker IA, Dosky KN, Alkass JE. Milk yield and composition of Karadi ewes with the special reference to the method of evacuation. J Duhok Univ 2009; 12(1): 210-215.

7. Pavón M, Fuentes JL, Lima T, Albuernes R, Efremov A, Perón N. Estudio de la producción de leche de la oveja Pelibuey, Pelibuey x Suffolk y Pelibuey $x$ Corriedale y el crecimiento del nacimiento al destete de sus crías. Rev Cub Reprod Anim 1987, 13(1): 39-49.

8. Instituto Nacional de Estadistica y Geografia (INEGI). Anuario estadistico de los Estados Unidos Mexicanos 2010. Aguascalientes, Ags, MX: INEGI; 2010.

9. National Research Council (NRC). Nutrient requirements of small ruminants sheep, goats, cervids, and new world camelids. Washington, USA: The national academic press; 2007. 
10 Poulton SG, Ashton WM. Studies on ewe's milk. $V$. The effect of high cereal diets on ewes and on the yield of milk and milk constituents. J Agric Sci 1972; 78 (02): 203-213.

11. SAS. Release 9.2. Cary (NC): SAS Institute, Inc. 2009.

12. Minitab. Release 16. Philadelphia (PA): Minitab, Inc. 2009.

13. Ünal N, Akçapinar $H$, Atasoy F, Yakan A, Uğurlu M. Milk yield and milking traits measured with different methods in Bafra sheep. Rev Méd Vét 2008; 159(10):497-501.
14. Neville TL, Meyer AM, Reyaz A, Borowicz PB, Redmer DA, Reynolds LP, Caton JS, Vonnahme KA. Mammary gland growth and vascularity at parturition and during lactation in primiparous ewes fed differing levels of selenium and nutritional plane during gestation. J Anim Sci Biotech 2013; 4(6):1-7.

15. Ochoa MA, Torres $G$, Ochoa AE, Vega $L$, Mandeville PB. Milk yield and composition of Rambouillet ewes under intensive management. Small Rum Res 2002; 43(3): 269-274. 